\title{
Influence of Culture in Handling Conflict Situation-With Special Reference to Indian Sub Cultural Diversity
}

\author{
Prabu. B. Christopher ${ }^{1} \&$ BhanuSree. D. Reddy ${ }^{1}$ \\ ${ }^{1}$ VIT Business School, VIT University Vellore, India \\ Correspondence: Prabu. B. Christopher, VIT Business School, VIT University Vellore, 632014, India. E-mail: \\ prabuchristopher.b@vit.ac.in
}

Received: December 11, 2013 Accepted: December 18, 2013 Online Published: January 26, 2014

doi:10.5539/ass.v10n4p31

URL: http://dx.doi.org/10.5539/ass.v10n4p31

\begin{abstract}
Personality is said to be the product of genes and environmental factors. Amid several environmental factors, culture seems to play an imperative role in shaping ones behavior. Studying the influence of culture on organizational behavior from heterogeneity perspective has become a predominant factor among the eminent researchers and academicians. Since it has been frequently stated that Indian studies are seems to be contradictory and inconsistent in its cultural study, this paper tries to address the difference between South Indian managers and other than south Indian Managers on their value systems and their Conflict management Style. T test and one way Anova are the statistical tests used to infer the collected data. Result shows that there is no major significant differences with respective to individual values exist between the south Indian and other than south Indian Managers except with the value system of Conformity at 1 per cent level of significance, where south Indian manager are seems to be somewhat traditional when compare to managers hail from other than south India and more over they are seems to be having withdrawal style of conflict management. There is no significant difference seems to exist among these managers with respect to other conflict management styles. Influence of years of stay away from birth place has also been analyzed where it shows external exposure has its influence on individual value.
\end{abstract}

Keyword: Sub Cultural diversity, conflict management styles

\section{Introduction}

Among several other factors Cultural values are considered to be one of the predominant factors in determining the organizational behavior. By assuming that individual is being influenced by the cultural background to have belief on social Structure, this paper tries to explore the influence of Individual values on organizational behavior with special reference to Conflict management style.

As per Hofstede, human nature and culture as inherited and learned behavior determines the human personality. Having this statement as base, several research works have been established in identifying the influence of national culture on Organizational behavior especially in the area of cross cultural studies. Transformational managers and Global managers are the words that are being used frequently by both academicians and practitioners in current market scenario which clearly shows that an individual should be in position to mold his or her behavior according to the situation rather being accustomed to one type of behavior or personality all the time. This theoretical explanation persey will not help practitioners to identify the behaviors among the team members. Rather it makes them to ponder the answers for queries like, what are all the behavioral difference exists among the employees? How to identify those similarities and differences? If practitioners are in position to answer these queries then it is rest assured that there are possibilities for them to bring value orientation to achieve the objective especially in multicultural environment.

\section{Literature Review and Purpose of This Study}

Sociologist advocates that values of society are acting as norms that differentiate one society from the other. These norms makes individuals of a society to act in particular fashion which differentiate individuals of different society, thus it has been termed as value orientation (Kluckhon, 1951). Subsequently researchers started to view values as core ideas from where people built their attitudes and preferences and learn how to lead their life and to achieve their ends. These cultural values are in the form of three elements normative, affective and 
directional. Value orientation in organizational context is considered to be the essential factor in determining the performance of the team especially multicultural team. Appreciable correlation is proved between the level of cohesiveness and Level of conflicting situation (Pelled, 1996; Jehn, Northcraft, \& Neale, 1999). These level of cohesiveness is able to achieve only if the afore said value orientation is given due importance. Understanding this fact, research works have started to apply disciplines like Anthropology, Sociology in understanding organizational behavior in various disciplines like marketing, finance, general management, human resources management etc. But majority of these studies are based on the concept of Homogeneity (Singh, 2008). This concept relies on applying a particular cultural dimension say for an example Individualistic tendency for the whole society or a nation. This may lead to false conclusion as it ignores the diversity which is existing within the nation. India is the best example though there is unity in political term (Bose, 1967) one cannot forget the fact of existing wide range of variation. These Variations can be identified in the form of geographical location, language, religion, caste etc. Antecedents of these variations can be understood if one can trace Indian history from $6^{\text {th }}$ century BC where people relished both materialistic and Spiritual Life (Basham, 1967). Many invaders like Turkish chieftain Mahmud, Alexander, Babar have invaded India and this invasion has ended up with Britishers in 1947. Apart from these influences, there is high influence of Scriptures, Mahabharata and Upanishads in molding the behavior by preaching certain religious norms. Mainly hierarchical caste system starting from Brahmins to Sutras also started influencing the behaviors of Indians. Globalization and Modernization has joined hands in molding the behaviors further in the form corporate culture. Hence Indians has got influenced by its own philosophy and External influence in the form of modernization. Gradually these both value systems started influencing the organizational life of Indians where they started to practice western management style along with their tradition, popularly termed as strange dualism. Because of this reason, studies that are made under Indian context in cultural angle have yielded inconsistent and contradictory result. Nevertheless Studies in Indian context, both empirical and conceptual studies have tried to identify the Indian organizational culture and Indian managers' organizational behavior (Sinha, 1984; Kanungo, 1985; Chakrborty, 1991; Tripathi, 1992; Sinha \& Kanungo, 1997; Fusilier \& Durlabhji, 2001; Kejriwal \& Venkat, 2004; Kanika \& Bhal, 2006; Nair, 2010). These studies have identified few characteristics of Indian mangers and organizational culture viz personalized relationship, hierarchical nature, lack of upward communication, caste influence, Individualistic tendency along with own traditional behavior. If we deeply look into these finding, the above said inconsistency seems prevailing in these findings which gives unclear picture on values.

\section{Purpose of the Study}

Based on the above review of literature it is clearly evident that regular monitoring of this value orientation is seems to be necessary among Indian employees especially with managerial cadres. Managers are often exposing to various conflicting and negotiating situation where they need conglomerated behavior in order to balance their organizational life. Thus analyzing the behaviors during conflicting situation is vital for an organization. Most of the studies on conflict forget conflict as an episode (James, 2009). Unless one is not able to mold his behavior accordingly, it may lead to dysfunctional conflict where emotions plays a vital role throughout conflict episode (Nair, 2007) and it may deteriorate the level of performance. If we take Indian studies made so far having sub cultural diversity as main focus, empirically they were able to prove few values that rules Indian managers, few among them are collectivism (Sinha, 2002), Gender Discrimination (Tisdell \& Regmi, 2005), High uncertainty avoidance (Joseph, 1973), Caste influence (Anant, 1974). Moreover it is clearly evident that managers are exposing to values just opposite to traditions, Nonviolence, interconnectedness, non-attachment due to the influence of globalization. In this line, this study tries to find out is there any differences exists among south Indian managers when compare to other managers who are hailing from places other than south India. As the above review of literature seems to have less concentration in linking the values and conflict management in Indian Context, this study tries to contribute to fill the existing gap.

\section{Research Methodology}

Having value orientation as base, major research works has been done especially taking cross-border assignment into consideration (Kobrin, 1994; Robert, 1998; Furnham, 2005; Cohen, 2009; Fotopoulos, 2011; McGuire, Garavan, \& Saha, 2006). The aforesaid research works has concentrated how personal values influences behaviors in different aspect such as work style in terms of decision making, handling conflict situations of different kind, consumer behavior from marketing perspective. Also how these values are making managers culturally competent to handle cultural issues in work place in international scenario have been pondered. Same way taking diversity that are existing within the nation in terms of age, race gender, language et al. (Haris \& Moran, 1996) along with the earlier studies such as Idocentric and Allocentric by Triandis (1985) researchers have started exploring the behavior of an individual in organizational context such as Machiavellistic tendency in 
Indian context (Cyriac \& Dharma, 1994), Role Conflict (Pandey, 1997), Ethical dilemma (Chatterjee, 2000) collectivist and individualistic tendency among Indians (Sinha, 2002). Taking research methodology what the aforesaid research have been used, have been considered for this study to explore the influence of sub cultural diversity on conflict management styles in Indian context.

\subsection{Sample Population}

After direct interaction with few project managers and got the information that they are facing many conflicting situations on all the sides, like Clients, subordinates, other micro and macro environment, mostly project managers and team leaders have been chosen for the study and all of them are working in IT field in Chennai, Bangalore and Hyderabad. Since Study is basically on south Indian managers, three states from south India have been chosen. IT field has been chosen in order to take the advantage of high multicultural density for comparative study. Finally 195 managers who have their birth place other than south Indian and 304 from south Indian managers participated in the survey.

\subsection{Measures}

Individual values have been measured by using PVQ developed by Schwartz, where ten individual values which has been identified as guiding principle. Those ten values are, Self-direction Stimulation, Universalism, Benevolence, Power, Achievement Security, tradition and conformity.

In order to measure organizational behavior using individual value, less pondered area in Indian context Conflict management styles have been chosen. Five conflict management styles, have been developed by many scholars viz Blake and Mouton (1964), Thomas (1976), Faria (1982), M. Afzalur Rahim (1983). Eminent scholars who have contributed in this area of research were also given inventories to measure the conflict management styles. Five major conflict management style according to the afore said researchers, are depend on two main aspects, One is cooperativeness and another one is assertiveness. Based on the level of importance given by the individual to these element may determines his or her conflict management style. Suppose if an individual is more assertive and having less cooperativeness then he or she may tend to be more competitive, if an individual seems to be less assertive and more cooperative the that individual tends to follow accommodative style of conflict management, if a person tries to be more assertive and more cooperative, that person may try to be more integrative and want to have win-win situation. If a person seems to be having none of the afore said two behaviors and he or she may always tend to avoid conflicting situation. And there are person who are ready to sacrifice to have few advantage, those kinds of individuals are always fall on the middle point, they have moderate behavior of assertiveness and cooperativeness. These style have been identified in this research by using statement which is modified statement of the proverbs used to evaluate the afore said styles, like "I always prefer open discussion in resolving conflict", "I always respect to the truth uttered by others". These statements are measured using 5 point likert scale.

\subsection{Statistical Tools}

Simple statistical tools $t$ test and Anova tools have been used.

\section{Interpretation and Discussion}

\subsection{Interpretation}

Table 1.

\begin{tabular}{|c|c|c|c|c|c|c|c|}
\hline \multicolumn{8}{|c|}{ Place of Birth } \\
\hline \multirow{2}{*}{ Conflict Management Style } & \multicolumn{2}{|c|}{ South Indian managers } & \multicolumn{2}{|l|}{$\begin{array}{l}\text { Other than } \\
\text { Managers }\end{array}$} & \multirow[t]{2}{*}{ Indian } & \multirow[t]{2}{*}{ t Value } & \multirow[t]{2}{*}{$\mathrm{P}$ value } \\
\hline & Mean & SD & Mean & SD & & & \\
\hline Forcing & 10.86 & 2.94 & 10.64 & 2.79 & & 0.82 & 0.41 \\
\hline Withdrawing & 9.87 & 2.86 & 9.34 & 2.61 & & 2.07 & $0.03 *$ \\
\hline Compromising & 9.57 & 3.20 & 9.59 & 2.90 & & 0.06 & 0.95 \\
\hline Smoothing & 9.79 & 3.30 & 9.85 & 3.23 & & 0.21 & 0.82 \\
\hline Collaborating & 10.16 & 3.31 & 10.59 & 3.34 & & 1.41 & 0.15 \\
\hline
\end{tabular}

Note: ** Significance at $1 \%$ level; * Significance at $5 \%$ Level. 
Since $\mathrm{P}$ value is less than 0.05 (Table 1) for withdrawing styles it shows that there is significant difference between managers who hailed from south India and managers from other than south India at 5 percent level of significance. South Indian managers are seems to employ withdrawal mode of conflict management styles when compare to south Indian managers. There is no significant difference exist among these managers as far as other conflict management styles are concern as all the $\mathrm{P}$ values are greater than 0.05 .

Table 2 .

\begin{tabular}{|c|c|c|c|c|c|c|c|}
\hline \multirow{3}{*}{ Individual Values } & \multicolumn{4}{|c|}{ Place of Birth } & \multirow{3}{*}{ Indian } & \multirow{3}{*}{ t Value } & \multirow{3}{*}{$P$ value } \\
\hline & \multicolumn{2}{|c|}{ South Indian Managers } & \multicolumn{2}{|c|}{$\begin{array}{l}\text { Other than } \\
\text { Managers }\end{array}$} & & & \\
\hline & Mean & SD & Mean & SD & & & \\
\hline Self-Direction & 11.02 & 2.10 & 11.34 & 2.04 & & 0.08 & 0.32 \\
\hline Stimulation & 6.85 & 1.44 & 6.69 & 1.54 & & 0.25 & 0.15 \\
\hline Hedonism & 9.66 & 1.95 & 9.89 & 1.91 & & 0.19 & 0.22 \\
\hline Benevolence & 11.09 & 2.483 & 11.48 & 2.40 & & 0.27 & 0.40 \\
\hline Achievement & 10.92 & 1.982 & 11.12 & 1.94 & & 0.26 & 0.20 \\
\hline Power & 6.44 & 1.758 & 6.31 & 1.67 & & 0.40 & 0.13 \\
\hline Universalism & 11.17 & 2.134 & 10.96 & 2.19 & & 1.05 & 0.29 \\
\hline Conformity & 10.53 & 2.244 & 10.94 & 2.06 & & 2.09 & $0.03 *$ \\
\hline Security & 7.16 & 1.659 & 7.33 & 1.54 & & 1.14 & 0.25 \\
\hline Tradition & 3.77 & 0.863 & 21.44 & 3.82 & & 0.187 & 0.85 \\
\hline
\end{tabular}

Note: ** Significance at $1 \%$ level; * Significance at $5 \%$ Level.

Since P value is less than 0.05 (Table 2) for the individual value conformity, there is significant difference between managers who hailed from south India and managers from other than south India at 5 percent level of significance. South Indian managers are seems to be more conventional and following more of tradition to some extent when compare to managers who hail from other than south India. There is no significant difference exist among these managers as far as other Individual values are concern as all the P values are greater than 0.05 .

Table 3.

\begin{tabular}{|c|c|c|c|c|c|c|}
\hline \multirow{2}{*}{ Individual Values } & \multicolumn{4}{|c|}{ Number of years away from birth place } & \multirow{2}{*}{ F Value } & \multirow{2}{*}{ P Value } \\
\hline & $<1$ & $1-5$ & $6-10$ & $>10$ & & \\
\hline \multirow{2}{*}{ Self-Direction } & 11.04 & 11.27 & 11.22 & 11.07 & \multirow{2}{*}{0.31} & \multirow{2}{*}{0.81} \\
\hline & $(2.54)$ & $(2.00)$ & $(2.29)$ & $(1.75)$ & & \\
\hline \multirow{2}{*}{ Stimulation } & 6.57 & 6.93 & 6.79 & 6.80 & \multirow{2}{*}{0.92} & \multirow{2}{*}{0.42} \\
\hline & $(1.80)$ & $(1.11)$ & $(1.69)$ & $(1.37)$ & & \\
\hline \multirow{2}{*}{ Hedonism } & $10.01^{\mathrm{ab}}$ & $10.25^{\mathrm{b}}$ & $9.50^{\mathrm{a}}$ & $9.52^{\mathrm{a}}$ & \multirow{2}{*}{4.46} & \multirow{2}{*}{$0.00 * *$} \\
\hline & $(2.14)$ & $(1.89)$ & $(1.90)$ & $(1.84)$ & & \\
\hline \multirow{2}{*}{ Benevolence } & 11.67 & 11.18 & 10.90 & 11.32 & \multirow{2}{*}{1.72} & \multirow{2}{*}{0.16} \\
\hline & $(2.49)$ & 2.12) & (2.73) & $(2.40)$ & & \\
\hline \multirow{2}{*}{ Achievement } & 10.86 & 10.91 & 11.15 & 11.01 & \multirow{2}{*}{0.42} & \multirow{2}{*}{0.73} \\
\hline & $(2.31)$ & (1.618) & (2.09) & (1.90) & & \\
\hline \multirow{2}{*}{ Power } & 6.01 & 6.50 & 6.40 & 6.48 & \multirow{2}{*}{1.61} & \multirow{2}{*}{0.18} \\
\hline & $(1.92)$ & $(1.72)$ & (1.55) & $(1.73)$ & & \\
\hline
\end{tabular}




\begin{tabular}{|c|c|c|c|c|c|c|}
\hline \multirow[b]{2}{*}{ Individual Values } & \multicolumn{4}{|c|}{ Number of years away from birth place } & \multirow{2}{*}{ F Value } & \multirow{2}{*}{ P Value } \\
\hline & $<1$ & $1-5$ & $6-10$ & $>10$ & & \\
\hline Universalism & $\begin{array}{l}11.22 \\
(2.23)\end{array}$ & $\begin{array}{l}10.91 \\
(1.92)\end{array}$ & $\begin{array}{l}10.81 \\
(2.62)\end{array}$ & $\begin{array}{l}11.30 \\
(1.88)\end{array}$ & 1.61 & 0.18 \\
\hline Conformity & $\begin{array}{l}10.32^{\mathrm{a}} \\
(2.46)\end{array}$ & $\begin{array}{l}10.35^{\mathrm{a}} \\
(1.95)\end{array}$ & $\begin{array}{l}10.70^{\mathrm{ab}} \\
(2.47)\end{array}$ & $\begin{array}{l}11.03^{\mathrm{a}} \\
(1.92)\end{array}$ & 3.14 & $0.02 *$ \\
\hline Security & $\begin{array}{l}7.38 \\
(1.67)\end{array}$ & $\begin{array}{l}7.14 \\
(1.64)\end{array}$ & $\begin{array}{l}6.99 \\
(1.75)\end{array}$ & $\begin{array}{l}7.35 \\
(1.46)\end{array}$ & 1.61 & 0.18 \\
\hline Tradition & $\begin{array}{l}3.84 \\
(0.95)\end{array}$ & $\begin{array}{l}3.70 \\
(0.90)\end{array}$ & $\begin{array}{l}3.69 \\
(1.11)\end{array}$ & $\begin{array}{l}3.81 \\
(0.78)\end{array}$ & 0.81 & 0.48 \\
\hline
\end{tabular}

Note: The values within the brackets refers to Standard deviation; ** Denotes Significant at one percent level; Different alphabets between distribution of individual values denotes significant at 5\% level using Duncan Multiple range test (DMRT).

Based on Duncan multiple range test (Table 3) those who are staying outside the birth place from one to five years are seems to have more hedonistic than other mangers falls on the other age group of less than 1 year and more than 6 years. P value of this age group (1-5) is less than .01 percent this shows that this difference is existed at 1 percent level of significance. Same way the age group more than ten years is seems to be more conservative as per Duncan Multiple range test where the difference is exists at 5 percent level of significance. There seems to be no such significant difference exists with respect to individual values among the managers of different age group other than afore said age group.

Table 4.

\begin{tabular}{|c|c|c|c|c|c|c|}
\hline \multicolumn{5}{|c|}{ Number of years away from birth place } & \multirow{2}{*}{ F Value } & \multirow{2}{*}{ P Value } \\
\hline Conflict management styles & $<1$ & $1-5$ & $6-10$ & $>10$ & & \\
\hline Forcing & $\begin{array}{l}10.99 \\
(2.83)\end{array}$ & $\begin{array}{l}10.15 \\
(2.82)\end{array}$ & $\begin{array}{l}10.94 \\
(3.14)\end{array}$ & $\begin{array}{l}10.92 \\
(2.73)\end{array}$ & 2.07 & 0.10 \\
\hline Withdrawing & $\begin{array}{l}9.95 \\
(2.89)\end{array}$ & $\begin{array}{l}9.44 \\
(2.58)\end{array}$ & $\begin{array}{l}9.62 \\
(3.13)\end{array}$ & $\begin{array}{l}9.68 \\
(2.59)\end{array}$ & 0.52 & 0.66 \\
\hline Compromising & $\begin{array}{l}9.56 \\
(3.02)\end{array}$ & $\begin{array}{l}9.00 \\
(3.02)\end{array}$ & $\begin{array}{l}9.00 \\
(3.26)\end{array}$ & $\begin{array}{l}10.29 \\
(2.99)\end{array}$ & 6.08 & $0.00 * *$ \\
\hline Smoothing & $\begin{array}{l}10.14 \\
(3.36)\end{array}$ & $\begin{array}{l}9.08 \\
(3.05)\end{array}$ & $\begin{array}{l}9.53 \\
(3.25)\end{array}$ & $\begin{array}{l}10.26 \\
(3.29)\end{array}$ & 3.59 & $0.01 *$ \\
\hline Collaborating & $\begin{array}{l}10.49 \\
(3.62)\end{array}$ & $\begin{array}{l}9.74 \\
(2.85)\end{array}$ & $\begin{array}{l}10.05 \\
(3.53)\end{array}$ & $\begin{array}{l}10.76 \\
(3.25)\end{array}$ & 2.53 & $0.05 *$ \\
\hline
\end{tabular}

Based on Duncan multiple range test (Table 4) those who are staying outside the birth place from more than ten years are seems to be compromise during conflict situation than other age groups and this difference exist at 1 percent level of significance. The same ages group are seems to be Accommodating and collaborating than other groups but at 5 percent level of significance.

\subsection{Discussion}

As per the analysis, it is clear that Individual values is being influenced by the birth place and also the exposure level that as an Individual is having apart from the birth place as here it shows that, hedonistic nature seems to be high. The dictionary meaning of hedonism has been discussed in two aspects, one is philosophical and another one is at psychological level. Though it has been described as behavior that has been motivated by pleasure seeking by avoiding the pain, it has been viewed from ethical point of view from philosophical angle where it 
supports the right that every individual is having in acquiring the pleasure using their power in order to enjoy the pleasure which has been advocated by Aristippus student of Socrates. Ethical Hedonism has also been used for the concept of Utilitarianism which believes in creating good to have happiness to the maximum extent to as many as possible. Since an individual is away from the birth place he or she may have chances to utilize the Individual freedom and started to achieve things what they desire for. So instead of looking Hedonism in a negative sense, may be because of individuality in a person due to his stay away from his birth place, he or she may make use of the freedom for acquiring more happiness also in positive way. As far as sub cultural diversity is concern there is no such difference seems to be existed as per the analysis, nevertheless south Indian managers seems to have more of conformity value. This gives us scope to rework on the study made by few authors like Santokh S. Anant (1974) on the influence of caste, religious and philosophical thoughts against modernization, nevertheless same study even agreed on those days itself saying that new generations are walking towards more of individualistic tendency where the influence of afore said forces seems to be less and prefer to be avoided. The experience of the person staying outside from the birth place more than ten years also seems to be having more individual value, conformity. This gives researchers the scope that age influences the individual value which can also be pondered on different organizational relationship.

Coming to the influence of Individual values on conflict management, similar to Kamil Kozan (1999) study in turkey, here also we can see the effect of individual value on the choice of conflict management, here it shows that south Indian managers are seem to withdraw themselves during the conflicting situation, this may be because of their conformity values. In Kamil Kozan study this has been empirically proved stating that those wore have the values of conservative, they may avoid the conflicting situation, and Conformity is one of the values coming under conservative as per Schwartz value dimension. Same way those who are staying outside from birth place for more than ten years are seems to use collaborating style during conflict situation along with Smoothing and compromising. Here this supports the earlier discussion on Ethical hedonism as Schwartz himself has placed this hedonism in both openness to change and Self enhancement. Thus it supports partially the hypothesized relation what Kamil Kozan has in his study stating those who have the value openness to change may be collaborative during conflict situation.

\section{Limitations and Conclusion}

This study has taken the sample from IT industry this may not be able to generalize to other field where behaviors are being decided mere by rules and regulations. Those factors are extrinsic and it has not been pondered much in this research. Only the number of years has been analyzed to know the influence of external factors on Individual values where there are numerous factors can be pondered. Nevertheless this research attempted to explore individual values of Indian managers on their organizational behavior in Indian context especially with special reference to conflict management styles. This may give scope for the researcher and academicians to move further to ascertain the relationship of much more organizational behaviors with Individual values.

\section{References}

Basham, A. L. (1967). The wonder that was India. Delhi: Rupa/Fontana Books.

Bose, N. K. (1967). Culture and society in India. Bombay: Asia Publishing House.

Chakraborty, S. K. (1991). Management by values: Towards Cultural congruence. Delhi: Oxford University press.

Cohen, A. (2009). Individual Values and the work family Interface. Journal of managerial psychology. http://dx.doi.org/10.1108/02683940910996815

Fotopoulos, C., Krystallis, A., \& Anastasios, P. (2011). Portrait value questionnaire's (PVQ) usefulness in explaining quality food-related consumer behavior. British Food Journal, 113(2), 248-279. http://dx.doi.org/10.1108/00070701111105330

Furnham, A., Petrides, K.V., Tsaousis, I., Pappas, K., \& Garrod, D. (2005). A cross-cultural-investigation into the relationships between personality traits and work values. The Journal of Psychology, 139(1). http://dx.doi.org/10.3200/JRLP.139.1.5-32

Fusilier, M., \& Durlabhji, S. (2001). Cultural Values of Indian Managers: An Exploration through unstructured interviews. International Journal of value based management. http://dx.doi.org/10.1023/A:1017525822608

Harris, P. R., \& Moran, R. T. (1996). Managing cultural differences and instructors guide. Houston: Gulf Publishing Company. 
Jehn, K., Northcraft, G., \& Neale, M. (1999). Why differences makes a difference: A field Study of diversity, Conflict and Performance in work groups. Administrative science quarterly, 44, 741-763. http://dx.doi.org/10.2307/2667054

Kanango, \& Misra. (1985). Declining work motivation in India. Indian Management.

Kanika, T., \& Debnath, B. N. (2006). Conceptualizing and measuring Gunas Predictors of workplace ethics of Indian Professional. International journal of cross cultural management.

Kejriwal, A., \& Venkat. (2004). Impact of Vedic worldview and Gunas on Transformational Leadership. Vikalpa.

Kluckhohn, C. (1951). In T. Parsons, \& E. Shils (Eds.), Values and Value-Orientations in the Theory of Action (pp. 388-433). Cambridge: Harvard University Press.

Kobrin, S. J. (1994). Is there a relationship between a geocentric mindset and multinational strategy? Journal of International Business Studies, 25(3), 493-512. http://dx.doi.org/10.1057/palgrave.jibs.8490209

Kozan, K., \& Ergin, C. (1999). The Influence of Intra Cultural value differences on conflict management Practices. International Journal of conflict management, 10(3), 249-267. http://dx.doi.org/10.1108/eb022826

MCGuire, D., Garavan, T. N., Saha, S. K., \& O’Donell, D. (2006). The impact of Individual values on human resources decision making by Line Managers. International Journal of Manpower, 27(3), 251-273. http://dx.doi.org/10.1108/01437720610672167

Nair, N. (2007). Towards the understanding the role of emotions in conflicts: A review and future directions. International Journal of conflict management.

Nair, P., \& Kamalanabhan, T. J. (2010). The impact of cynicism on ethical intentions of Indian managers: The moderating role of seniority. Journal of International Business Ethics.

Pandey, S., \& Kumar, E. S. (1997). Development of a measure of Role conflict. The International Journal of Conflict Management 1997, 8(3), 187-215. http://dx.doi.org/10.1108/eb022795

Pelled, I. (1996). Democratic Diversity, Conflict and Group Outcomes: An Intervening Process theory. Organization Science, 17, 615-631. http://dx.doi.org/10.1287/orsc.7.6.615

Roberts, K., Kossek, E. E., \& Ozeki, C. (1998). Managing the global workforce: Challenges and Strategies. Academy of Management Executive, 12(4), 93-106.

Singh, S. K., Srinivasan, V., Sista, S., \& Parashar, M. (2008). Cross Concept ualisation: A case for Multiple national cultures In India. IIMB Management Review.

Sinha, J. B. P. (1984). A Model of Effective Leadership Styles in India International. Studies of Management and Org, $\operatorname{XIV}(2-3), 86-98$.

Sinha, J. B. P., \& Kanungo. (1997). Context sensitivity and balancing in Indian organizational Behavior. International Journal of Psychology, 32(2), 93-105. http://dx.doi.org/10.1080/002075997400890

Speakman, J. (2009). A Re-evaluation of conflict theory for the management of Multiple Simultaneous conflict episodes. International Journal of conflict management.

Tripathy. (2006). Human Values (2nd ed.). New age international publication.

\section{Copyrights}

Copyright for this article is retained by the author(s), with first publication rights granted to the journal.

This is an open-access article distributed under the terms and conditions of the Creative Commons Attribution license (http://creativecommons.org/licenses/by/3.0/). 